\title{
(2) \\ To Strengthen the Teeth and Harden the Gums - Teeth blackening as medical practice in Asia, Micronesia and Melanesia
}

\author{
Thomas J. Zumbroich
}

\section{Research}

\begin{abstract}
Teeth blackening with agents of plant and mineral origin used to be the most wide-spread form of bodily inscription in parts of Asia, Micronesia and Melanesia, and I argue here that it can be productively studied as a medical practice. Ethnographic evidence supports that teeth blackeners became integrated into indigenous systems of medicine in which they fulfilled different purposes. They aided the recovery from the physically challenging teeth filing procedure, provided a primary form of preventive oral care and treated acute oral afflictions. Frequently used teeth blackening agents were derived from plants (e.g., Paederia foetida L. or Punica granatum L.) which were traditionally considered of high medical value and, from a biomedical perspective, had a high content of bioactive constituents. Biomedical data also validate the usefulness of many blackening plant extracts for improving oral health and suggest efficacy against other diseases prevalent in tropical climates, e.g., diarrheal or intestinal parasitic diseases. An assessment of the risk-benefit balance of teeth blackening suggests that, despite concomitant carcinogenic and other toxic risks, especially from chronic application, the practice could have made a positive contribution to health status in many societies before Western contact. The unique dynamic of medical utility embedded in diverse symbolic ascriptions might have provided the basis for its adoption in so many cultures of Asia, Micronesia and Melanesia.
\end{abstract}

\section{Introduction}

A mouth full of teeth 'as black as pomegranate seeds' (Leendertz 1890) used to be a common sight across much of Southeast Asia and beyond (Figures 1,2). Around the arrival of European colonial powers, to dye one's teeth black had become the most universal device of permanently marking the body. In Asia teeth blackening was at- tested from Sumatra along the Indo-Malaysian archipelago to Timor, and from peninsular Malaysia across the mainland to Yunnan and into the northwest of India as far as Manipur, Assam and Sikkim. Beyond the borders of Southeast Asia it also had become widespread in Taiwan and Japan as well as reaching the islands Palau, Yap and Guam in Micronesia. The southeasterly limit of the practice extended to New Britain, New Ireland and the Solomon Islands in Melanesia. (Figure 3). Beyond the borders of Southeast Asia it had also become widespread in Taiwan, Japan as well as parts of Micronesia and Melanesia. From about the sixteenth century into the last century, extrinsic political and religious influences discouraged and even penalized dental modifications while propagating a Western ideal of unadulterated 'white' teeth. Consequently, teeth blackening has become abandoned almost everywhere by now.

Much of the anthropological discussion on the body as a canvas has been focused on the cultural constructs surrounding corporeal inscriptions which marked the skin in

\section{Correspondence}

Thomas J. Zumbroich, 2409 Arpdale Street, Austin, TX 78704, U.S.A.

zumbroich@yahoo.com

Ethnobotany Research \& Applications 9:097-113 (2011)

Published: March 20, 2011 


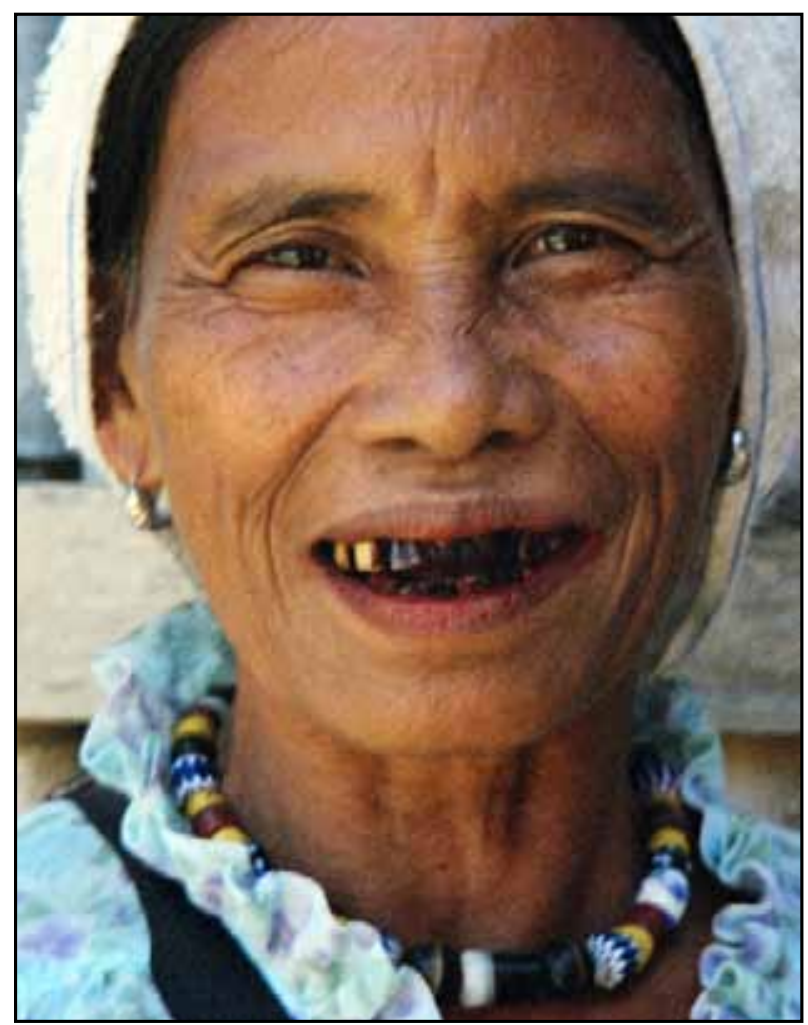

Figure 1. Gaddang elder with black teeth as a consequence of a lifelong, regular application of tubug, the wood tar of Psidium guajava L. (Myrtaceae). Besides esthetic considerations, the practice was motivated by the belief that blackening teeth prevented the tutuk, 'tooth worm', from invading the teeth and slowly eating them. Ikkalakad, Cordillera Central of northern Luzon, 2003.

the form of tattooing, painting, scarifying, etc. (Schildkrout 2004). Teeth blackening, too, served to define individual and cultural identity (Reid 1988, Zumbroich \& SalvadorAmores 2009), but beyond that had a unique dimension: The medium of inscription, the 'ink' so to speak, appears to have mattered greatly. Over time sophisticated processes emerged as different ethnolinguistic groups chose specific plants and earths high in minerals which they would employ in sometimes lengthy and complex procedures to dye their teeth.

Beginning with the earliest European observations, it was noted that teeth blackening appeared to 'preserve' the teeth (e.g., on the Tagalog in Luzon; Morga 1904) and had an overall beneficial effect on oral health. A more recent qualitative study on hundreds of teeth extracted for periodontal reasons from Vietnamese with dentitions dyed black in a traditional manner, found that none of these

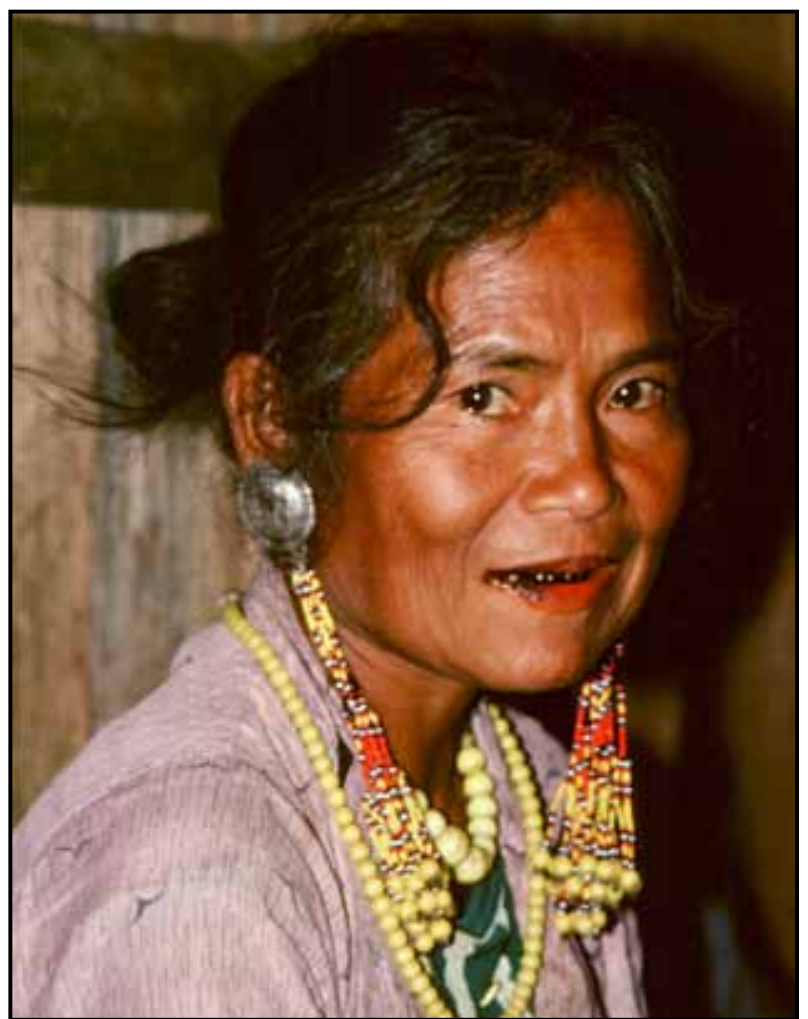

Figure 2. A woman belonging to the Higaonon-Banwaon indigenous group in Kiudto, a small settlement in the mountains between the provinces of Bukidnon and Agusan del Sur of north central Mindanao (1983). Her blackened teeth contrast with lips reddened from betel chewing, a distinct, yet related practice. Across Mindanao the vine Epipremnum pinnatum (L.) Engl. (Araceae) used to be a popular teeth blackener, sometimes specifically appreciated for its slightly narcotic effect that could be experienced from chewing it.

teeth displayed any signs of caries (Flynn 1977). Another investigation addressing the effect of teeth blackening among Solomon islanders found a tendency for improved periodontal health, for which variables other than a lifelong practice of teeth blackening seemed to be unable to account (Bailit 1968).

This study is the first to provide a cross-cultural perspective of the connection between teeth blackening and medical benefits in Asia, Micronesia and Melanesia. I will explore the hypothesis that across this region traditional knowledge associated specific benefits, especially for oral health, with the practice of teeth blackening, and that in turn ethnomedically valued plants were most frequently employed in the process. I will further draw on the biomedical paradigm to evaluate both traditionally implied and other potential health benefits as well as the associated risks, in order to analyze the risk-benefit balance 


\section{Zumbroich - To Strengthen the Teeth and Harden the Gums - Teeth blackening as medical practice in Asia, Micronesia and Melanesia}

of the blackening process. Finally, I will elaborate on the issue of teeth blackening as a medical practice within a broader geographical context and in relation to other symbolic meanings of the process.

\section{The indigenous perspective}

Opportunities to directly explore the medicinal dimension of teeth blackening in its traditional context, e.g., through health surveys of different populations, are all but absent by now. To accomplish the wide geographic scope of this study (Figure 3), my primary resources for the traditional knowledge expressed in the practice were historical reports and previous ethnographic fieldwork. These sources were extensively surveyed and any pertinent information on teeth blackening compiled in a database, upon which the arguments presented here are based. It was possible to identify different, yet interconnected medicinal functions that traditional knowledge ascribed to the process of blackening in the area of oral health.

\section{Aftercare for teeth filing}

In many cultures teeth blackening played a role as a rite of passage into adulthood since black teeth were read as visible sign of sexual maturity. There was, however, also a practical reason why blackening occurred during this particular stage of life: It was closely linked to the filing of the visible front teeth, which, especially in Island Southeast Asia, maturing boys and girls underwent at the same time. Using a stone or metal implement, the reshaping of teeth could take a variety of forms, from creating a sawtooth shape to filing deep grooves into the labial surfaces or evenly sawing the crowns as far as the gum line (e.g., Wilken 1888). This painful procedure was accompanied by soft tissue lacerations and bleeding which were sometimes welcomed as a fertility rite (Kennedy 1953). Filing could expose the pulp cavity of teeth and occasionally ended fatally due to post-surgery complications (Smith 1951).

Teeth blackeners were applied subsequent to the operation to help in different ways with the recovery from the trauma. Immediately after the procedure, tarry or resinous substances were smeared onto the stumps, so as to provide a seal to the injured part of the tooth (e.g., by the Batak of Sumatra or Agta of Casiguran in Luzon; Hagen 1884, Headland 1977). In some cases teeth blackening preparations were applied in order to impart specific medicinal benefits to the patient. In Sumba, applying a preparation from smashed candle nuts (Aleurites moluccana (L.) Willd., Euphorbiaceae) was thought to reduce the pain while imparting a lustrous black at the same time (Hoskins 1990), whereas the Jarai of the highlands of central Vietnam applied a poultice of hre' Nyek (Aganosma sp., Apocynaceae) to reduce infections as well as blacken the teeth (Dournes 1969). The Toraja of central Sulawesi filled the leaves of Jatropha curcas L. (Euphor- biaceae) with pounded Curcuma sp. (Zingiberaceae) root to fashion a quid on which to bite for relief after the surgery; but just the leaves were also chewed for the same purpose and to impart a black color to the teeth (Adriani \& Kruyt 1912, Kruyt 1938).

\section{Preventive oral care}

After the initial application of teeth blackener, whether after filing or not, the practice was in some societies continued for a number of years or even throughout one's whole life on a nearly daily basis (see Figure 1). Besides aesthetic considerations, such frequent use of teeth blackeners was motivated by the conviction that it provided a general form of preventive care for both teeth and gums. The understanding of the medicinal utility of the teeth blackening procedure was founded on local interpretations of bodily processes, such as the widely held belief that a 'tooth worm' was responsible for eating cavities into the teeth; hence from Vietnam to the Philippines teeth blackener was applied to specifically protect against the deleterious action of the 'tooth worm' (see Figure 1; Huard 1951, Skeat 1900, Zumbroich \& Salvador-Amores 2009). On the Solomon Islands, teeth blackening was thought to promote 'hardening the gums' in order to 'prevent sore gums' (Ivens 1918, 1930). In central Vietnam, where teeth blackening found some of its most complex expressions, different powders and unguents 'to guarantee the strength of teeth' became closely kept family secrets. In cases where their key ingredients were revealed, they turn out to be nothing else than those constituting blackening agents (Sallett 1938).

On the one hand, blackened teeth were aesthetically associated with clean teeth as is, e.g., linguistically represented in the Yabem language of Northeastern New Guinea where dẳalūn, composed from dẳa 'black dye clay' and Iūn 'tooth', came to mean 'to clean the teeth' (Schellong 1890). On a practical level, the teeth blackening process itself required a certain level of dental hygiene. Blackening was often done in the evening after the main meal, and mechanical cleaning of the teeth became an integral part of its protocol. So that the blackener adhered properly, food particles from the meal had to be removed, e.g., by rinsing and rubbing the teeth with the husk of an areca nut (Bailit 1968, Salvador-Amores pers. comm. 2009).

\section{Treatment of acute oral conditions}

Local pharmacopoeias provide a number of examples in which the same material used for teeth blackening doubled as a treatment for specific dental and periodontological complaints. Paederia foetida L., Rubiaceae (see also below) had a wide-spread reputation as a treatment for dental problems, both in places where it was used for teeth blackening and elsewhere. In Java the reddish latex from J. curcas was used not only to dye teeth, but also as a treatment for bleeding gums (Filet 1855, Heyne 


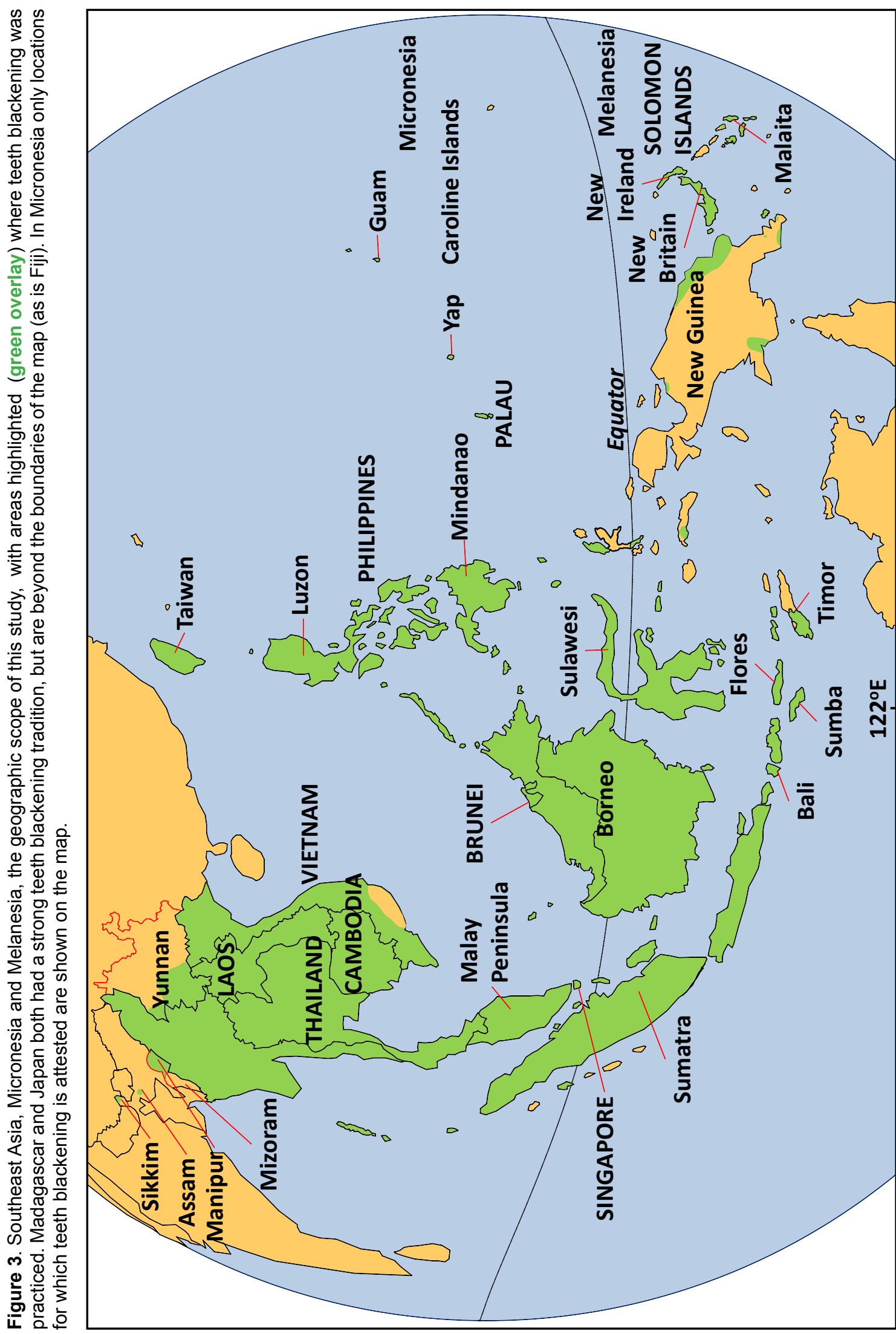

www.ethnobotanyjournal.org/vol9/i1547-3465-09-097.pdf 
Zumbroich - To Strengthen the Teeth and Harden the Gums -

Teeth blackening as medical practice in Asia, Micronesia and Melanesia

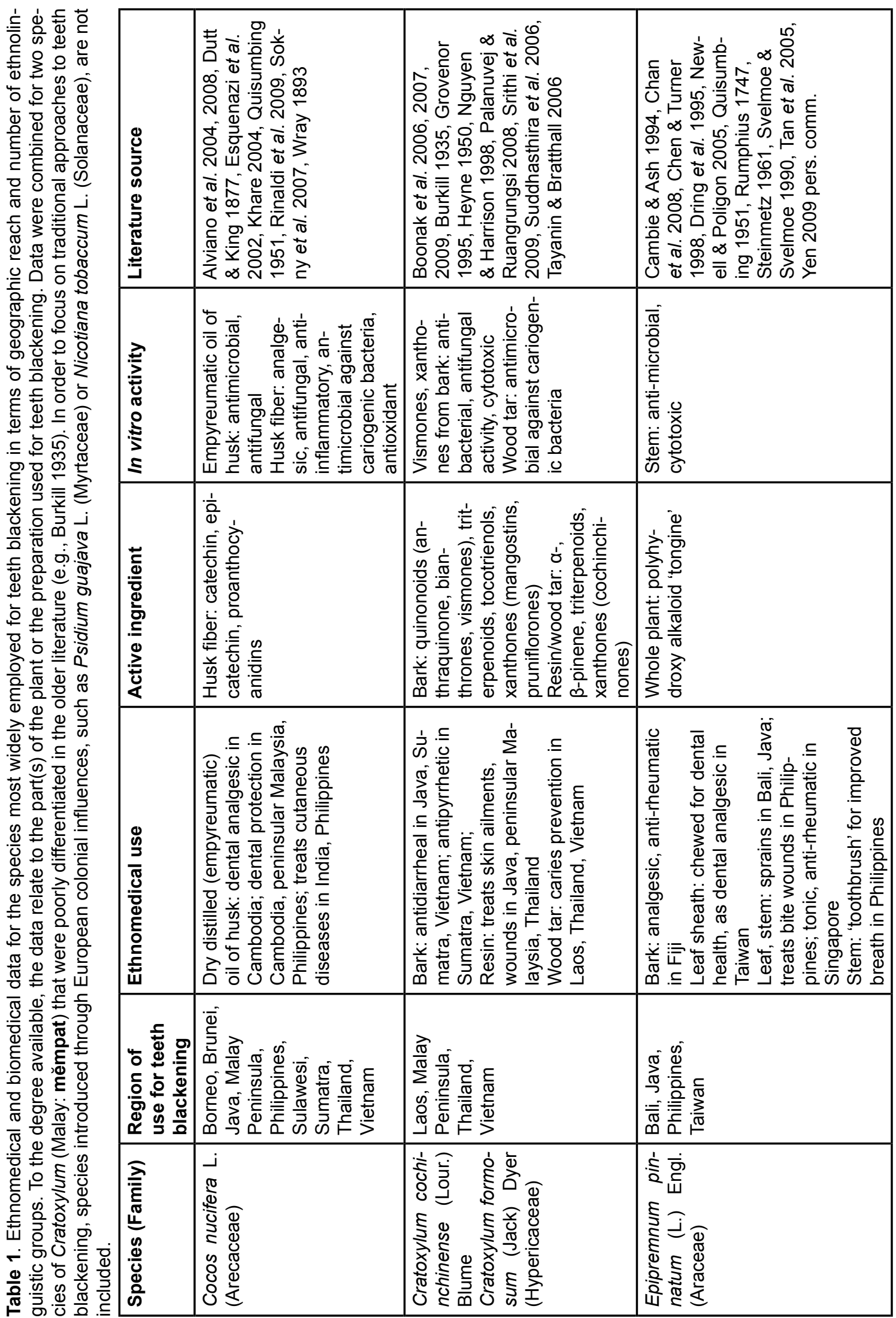




\begin{tabular}{|c|c|c|c|}
\hline 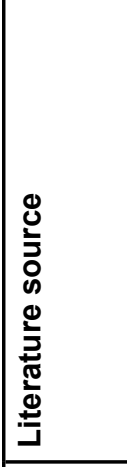 & 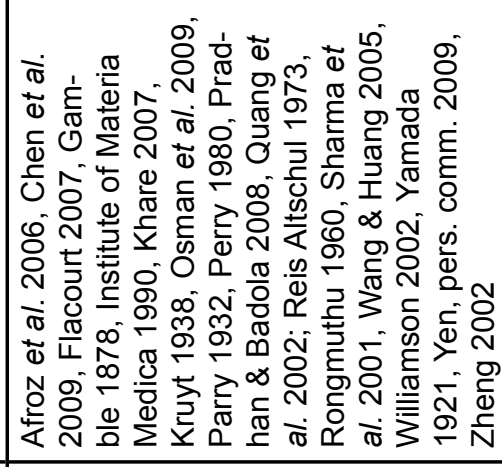 & 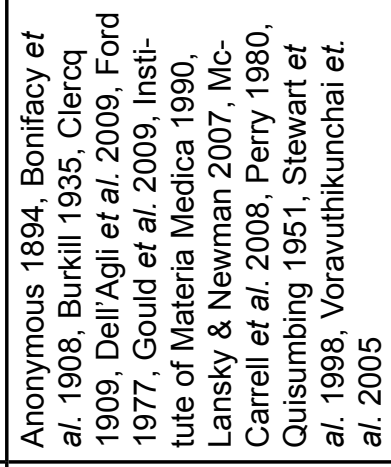 & 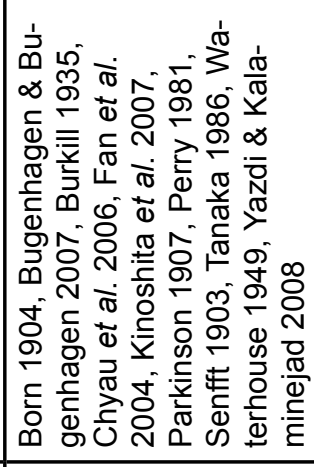 \\
\hline 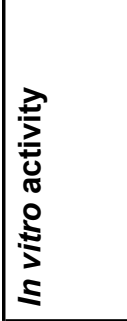 & 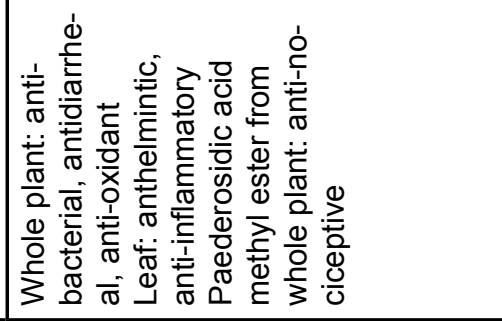 & 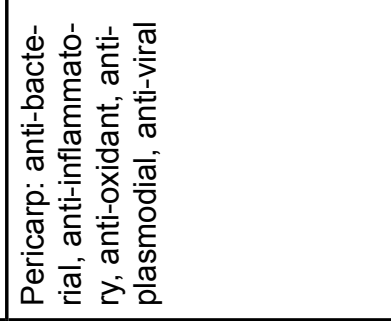 & 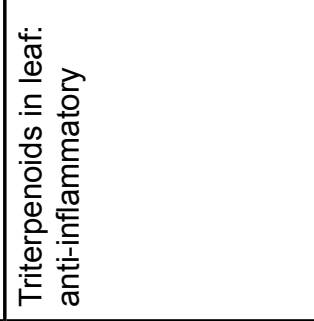 \\
\hline 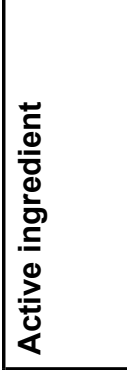 & 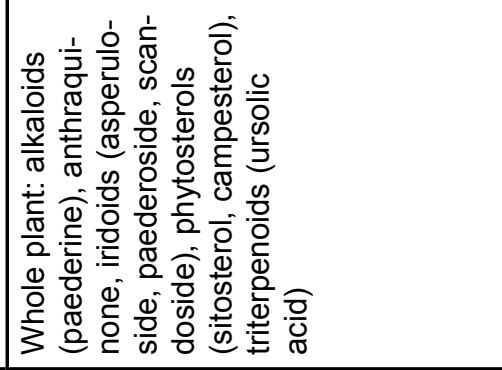 & 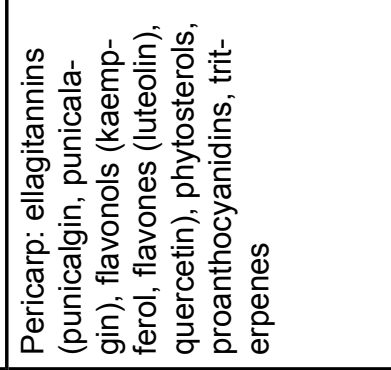 & 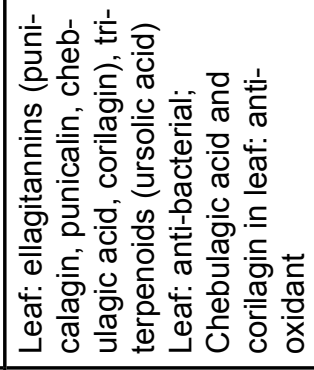 \\
\hline 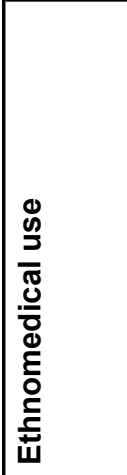 & 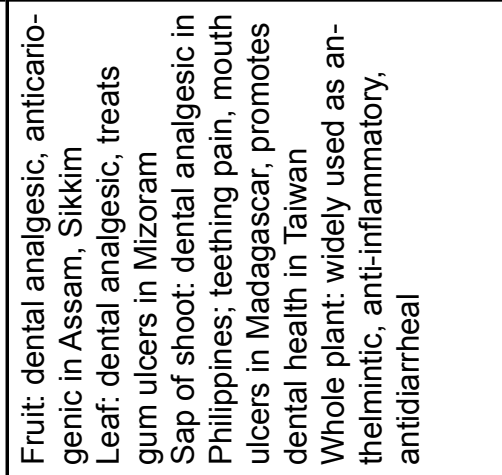 & 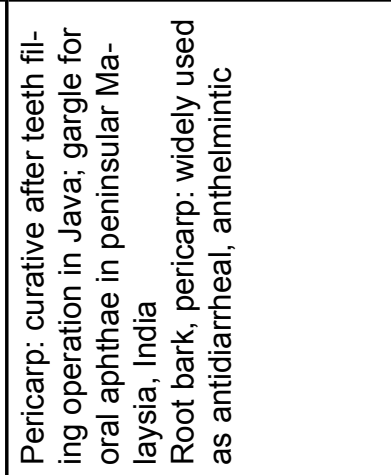 & 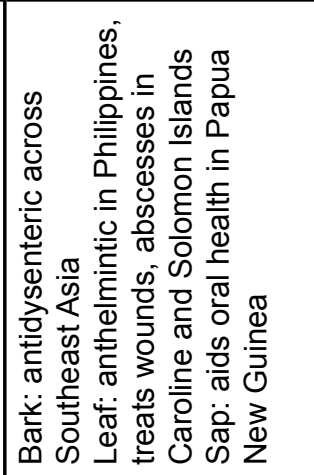 \\
\hline 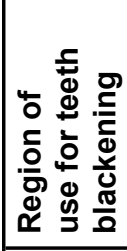 & 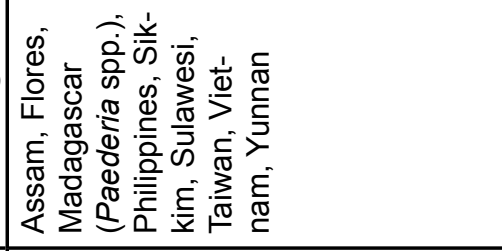 & 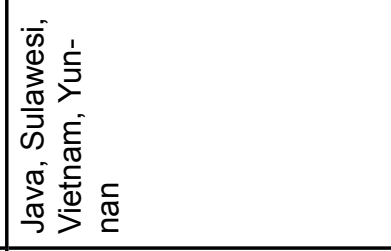 & 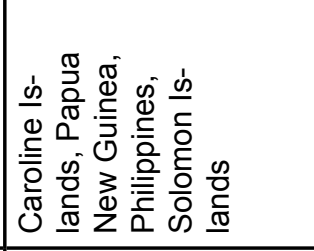 \\
\hline 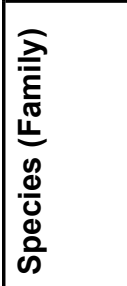 & 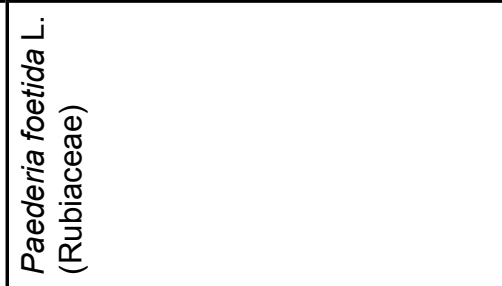 & 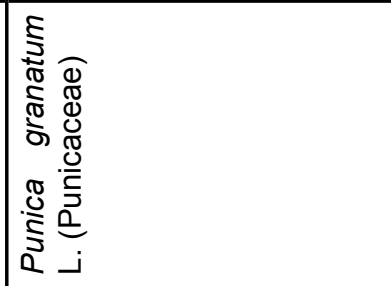 & 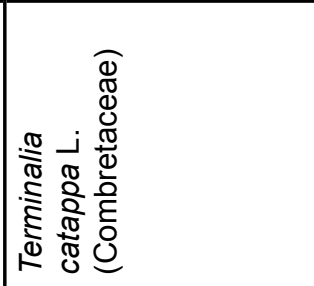 \\
\hline
\end{tabular}




\section{Zumbroich - To Strengthen the Teeth and Harden the Gums - Teeth blackening as medical practice in Asia, Micronesia and Melanesia}

1951). The sap and wood tar of Antidesma heterophyllum BI. (Phyllanthaceae) and Solanum verbascifolium L. (Solanaceae) [Note that this species is ill defined and has been divided into many different species.] were applied to blacken as well as to treat painful teeth while the leaves of the latter also found use to clean the mouth after teeth filing (Burg 1884-1885, Clerc 1909, Hasskarl 1845). There is also physical evidence that teeth blackener was specifically applied to 'fill' carious lesions (Gleichauf 1979).

\section{Use of medicinally potent plants}

As I have shown, the process of teeth blackening was locally intertwined with traditional approaches to oral health. These actual or perceived benefits were primarily mediated by plants selected for the practice. Certainly, alternative and readily available, but unspecific sources of blackener were available: The tarry soot rising from the fire and blackening the roof almost like lacquer was poetically referenced as a simile for teeth blackener, but was almost never used as such (Laade 1999). The Manóbos of Mindanao preferred the scrapings from the bottom of a pot to paint their lips black, but resorted to plant derived agents to blacken their filed teeth (Garvan 1931).

Was medicinal potency then a pertinent quality in the plant species chosen for teeth blackening? At least correlative evidence for this hypothesis can be provided by elaborating the ethnomedical profile for blackening agents which had shared use over a wide geographic area by speakers of diverse linguistic families. Among the numerous plants formerly utilized for teeth blackening (Zumbroich 2009 and unpublished data) only a few stand out because their use as teeth blackeners was convincingly documented for a number of ethnolinguistic groups across a wide geographic area. Table 1 presents data on this group of teeth blackening agents.

The species geographically most widely used for teeth blackening was $P$. foetida, of which every part, from the root to the fruit, was chewed for this purpose. It is also one of the species for which the nexus between teeth blackening and medicinal activity can be documented particularly well. Paederia foetida was an important constituent of many traditional medical systems, e.g., as an anti-inflammatory or antidiarrheal, but there are also numerous specific references attesting to its effectiveness in preventing and treating disorders of the oral cavity (for references see Table 1); for example, in Madagascar it was first chewed by the mother and then rubbed on the gums of teething children to lessen their discomfort (Flacourt 2007).

Another chewing agent often employed in teeth blackening was the vine Epipremnum pinnatum (L.) Engl. (Araceae) (now a common house plant known as 'Pothos vine'), of which root, stem and leaf sheath were chewed. The vine was thought to alleviate dental ailments, but also to have a narcotic quality which imparted a 'soothing, seda- tive feeling' (see Figure 2; Garvan 1964). In Fiji, where teeth remained unadorned, the bark of $E$. pinnatum had traditional medicinal uses as a treatment for rheumatism, neuralgic headache, back pain and muscular spasm (Cambie \& Ash 1994). Tonga, a remedy derived from an aqueous extract of the bark of E. pinnatum and Premna tahitensis Schauer (Lamiaceae), was introduced from Fiji to London in the late nineteenth century to treat rheumatism (Brown 1882, Ringer \& Murrell 1880) and remained a part of Western pharmacopoeias into the 1960s (Wilson \& Jones 1967).

Collecting the oily smoke from burning coconut shells on a piece of iron produced so-called empyreumatic oil of coconut. In Southeast Asia it was a frequently applied teeth blackening agent, but was also sought for its therapeutic utility as a topical treatment for toothache or skin ailments. Teeth blackening preparations from the resin and wood tar exuded from burning stem sections of either of two closely related Cratoxylum species (Hypericaceae) were popular in mainland Southeast Asia. Among the diverse uses of the medicinally potent resin of these plants was also the prevention of tooth decay (Suddhasthira et al. 2006, Tayanin \& Bratthall 2006).

The pomegranate tree (Punica granatum L., Lythraceae) was introduced to Southeast Asia in the early first millennium C.E. and became widely cultivated across the region not just for culinary, but also medicinal uses, in particular to treat diarrhea and intestinal parasites (Burkill 1935). Pomegranate rind made a very effective teeth blackener when it was chewed while sipping coconut water in which a chunk of iron had been submersed. In Java this teeth blackening mixture was traditionally considered a suitable treatment for discomfort and complications after the teeth filing operation (Anonymous 1894, Clercq 1909). In effect comparable blackening mixtures were compounded in Melanesia, Micronesia and the Philippines by combining sap, leaves or sprouts of Terminalia catappa L. (Combretaceae) and earths high in iron or manganese which were attributed with the ability to improve oral health (e.g., Bugenhagen \& Bugenhagen 2007).

\section{The biomedical perspective}

\section{Health benefits}

The outlined indigenous perspective of teeth blackening as a preventive and therapeutic tool for oral disorders raises the issue how it reconciles with a biomedical view of the practice. The Viet people of Vietnam applied multiple layers of blackener over etched, but otherwise unfiled teeth to leave a substantial coating (Huard 1951). If such teeth blackener was applied in a manner that sealed the grooves of the chewing surfaces so as to keep food particles and germs out of them, it provided a measure of physical protection for the teeth. Modern dental science has documented dental sealants as a very effective 
means of precluding cavities by blocking the penetration of demineralizing acids into the grooves of the teeth (Harris et al. 2009).

Where only moderate teeth filing had abraded the dental enamel on otherwise healthy teeth, teeth blackener potentially prevented pulpal infections and associated pain by occluding the now exposed dentinal tubules on the filed surfaces (Tronstad 2009). In cases of severe teeth filing that sometimes reached down to the gum line, the application of tarry blackeners to the stumps of the teeth provided some level of protection to the opened pulp cavity, both by providing a physical barrier or by antibacterial action, e.g., from the wood tar of Citrus spp. (Rutaceae) containing essential oils (Arias \& Ramón-Laca 2005, Hagen 1884). However, it is unlikely that this could have entirely prevented external irritations and inflammation of the pulpa and thus its ultimate necrosis (Tronstad 2009).

It has been suggested that one of the factors responsible for improved oral health status in a teeth blackening community was the overall increased attention to oral hygiene which accompanied the blackening procedure, especially after a meal and before sleep (Bailit 1968). Where teeth blackening was accomplished by regular and prolonged chewing, as for example with the widely used $E$. pinnatum or the young shoots of Dionychia bojerii Naud. (Melastomataceae) or Mussaenda arcuata Lam. ex Poir. (Rubiaceae) (Vallier 1898) in central Madagascar (see also Table 1 , Zumbroich 2009), this chewing increased salivary flow, an action known to benefit both hard and soft tissues of the mouth in multiple ways (Dawes 2008).

Pharmacological action of plant metabolites played a primary role in any preventive or curative action of teeth blackeners. Since a necessary selection criterion for a plant was its ability to blacken teeth, this capability was tied to the presence of secondary metabolites, thus providing a pre-selection for therapeutic activities. Extensive chewing or processing by heat aided the extraction and efficacy of bioactive constituents. In vitro studies with actual teeth blackener or closely related preparations have been able to show in select cases biological activities that match the therapeutic experiences reported by indigenous practitioners. Particularly relevant are antimicrobial activity, especially against cariogenic bacteria, anti-inflammatory as well as anti-nociceptive qualities (Alviano et al. 2008, Boonak et al. 2009, Suddhasthira et al. 2006, Tayanin \& Bratthall 2006). To attribute therapeutic action to specific compounds can prove difficult, given the complex composition of some teeth blackeners and the paucity of laboratory studies directly addressing this issue; nonetheless a strong case can be made for certain classes of compounds.

Plant polyphenols are a broad group of compounds that include hydrolyzable tannins (e.g., ellagitannins), pro- anthocyanidins (polymeric flavanoids, also known as condensed tannins) and various other flavonoids (e.g., kaempferol, quercetin). Across the study area a significant content of phenolic compounds is found in many species employed for teeth blackening, such as those belonging to Fabaceae (Albizia lebbeck (L.) Benth., Erythrina variegata L., Tamarindus indica L.), Myrtaceae (P. guajava, Rhodamnia cinerea Jack, Rhodomyrtus tomentosa (Aiton) Hassk.) or Rhizophoraceae (Bruguiera gymnorhiza (L.) Savigny, Rhizophora sp.; see also Table 1). Phenolics contributed to the actual teeth blackening by turning dark from oxidation or by forming black insoluble precipitates when reacting with metal, typically ferric $\left(\mathrm{Fe}^{3+}\right)$, ions. In vitro and animal studies have shown that polyphenols interact with oral bacteria, that are known etiological agents of caries disease (e.g., Streptococcus mutans Clarke), so as to decrease dental plaque accumulation and the virulence of these bacteria. Polyphenols can also reduce periodontal disease by virtue of their antioxidant properties that reduce oxidative stress (Petty \& Scully 2009). Other, e.g., anti-nociceptive and anti-inflammatory qualities, have been demonstrated for polyphenol-rich plants extracts (Table 1, see Cocos nucifera L., Arecaceae) and likely relate to their use in teeth blackening.

Xanthones are the most prominent bioactive compounds in the bark or the dark exuded resin of trees belonging to the family Clusiaceae, of which Garcinia mangostana L. and Cratoxylum spp. (formerly in Clusiaceae) were employed for teeth blackening. Xanthones are responsible for the inhibitory effect on cariogenic bacteria observed with teeth blackening preparations from Clusiaceae (Boonak et al. 2009, Pedraza-Chaverri et al. 2008); though, given the range of biological activities that xanthones are known to mediate, other therapeutic contributions are plausible, too (Pinto et al. 2005). Activity against cariogenic bacteria has also been shown for the triterpenoid ursolic acid (Liu 1995) present, e.g., in the leaves of $P$. foetida, $P$. guajava or T. catappa (Table 1, Gutiérrez et al. 2008), whereas other triterpenoids contained in teeth blackeners might elicit anti-inflammatory and anti-nociceptive responses. Also of note are iridoids (monoterterpenoid lactones) from a number of Rubiaceous plants employed in blackening, such as M. arcuata, P. foetida or Rothmannia macrophylla (Hook. f.) Bremek (Ling et al. 2001, Marcello et al. 1984). Iridoids can react with proteins to generate a dark dye to cause teeth blackening, but might also contribute to the medicinal effects of the procedure (Chen et al. 2009).

Indigenous testimony typically gave no indication that teeth blackening was associated with any medicinal benefits beyond the oral cavity, yet from a biomedical perspective this appears very likely. There is an increasing amount of evidence that poor oral health can be linked to cardiovascular disease, cancer, low birth weight preterm babies, diabetes and various other conditions. Bacterial exposure and increased serum levels of inflammatory me- 


\section{Zumbroich - To Strengthen the Teeth and Harden the Gums - Teeth blackening as medical practice in Asia, Micronesia and Melanesia}

diators as a consequence of periodontitis are thought to play an important role in these linkages (Fitzpatrick \& Katz 2009, Pihlstrom et al. 2005). If blackening one's teeth effectively reduced the prevalence of periodontal disease by impacting the pathogenic microflora of the mouth, secondary effects would have been reducing various disease risks or improving their outcomes. Teeth blackening likely also had an effect on disorders of the gastrointestinal tract, especially diarrheal diseases that have high prevalence in tropical regions. The usefulness of polyphenolrich plant extracts in controlling the symptoms of diarrhea through a variety of mechanisms, e.g., their astringency, antioxidant or antimicrobial properties, is well established, but other phytochemicals found in teeth blackeners, such as triterpenoids could have played a role as well (Voravuthikunchai et al. 2005).

A number of plants used for teeth blackening had a scientifically validatable reputation as anthelmintics, e.g., different parts of $P$. foetida, the leaves of $T$. catappa, the latex of $J$. curcas or the bark of $G$. mangostana (Table 1, Burg 1885, Quisumbing 1951). Frequent applications of blackener could therefore have reduced the helminths load in human intestines. A prophylactic effect on malaria is similarly plausible in certain cases; e.g., a number of Terminalia species have significant antiplasmodial activity (e.g., Jonville et al. 2008, Muganga et al. 2009), and low doses of unripe pomegranate peal can be effective in preventing malaria while at the same time also reducing the incidence of other infectious diseases (Dell'Agli et al. 2009). The regular ingestion of blackening plant preparations pre-selected for their medicinal potency could therefore have had broad significance for health maintenance.

The discussion has so far been focused on plant extracts, but earths or minerals high in iron, copper or manganese sometimes played an important role in the teeth blackening process where they provided the metallic component of organo-metallic complexes. Only occasionally encountered in Southeast Asia, these earths were integral to teeth blackening in parts of Micronesia and in a region of Melanesia centered on New Britain. Some of the descriptions of their use bear out connections to geophagy, as their taste was specifically appreciated (Lichenberk 2008, Rumphius 1999). Teeth blackening also involved metal solutions, produced by corroding pieces of iron or dissolving relatively pure minerals, such as 'bluestone' $\left(\mathrm{CuSO}_{4}\right)$. While many metal compounds exhibit some bactericidal activities by themselves, recent studies have demonstrated that the antimicrobial activity of pomegranate rind is significantly enhanced by the addition of metal salts (Gould et al. 2009, McCarrell et al. 2008). Another plausible contribution to dental health by inorganic components of teeth blackeners are trace elements with welldocumented effects on the mineralization of teeth (Lewis \& Elvin-Lewis 2003).

\section{Health risks}

Indigenous reports only noted the discomfort during the actual blackening procedure, such as a burning sensation in the mouth, but some of the ill effects might have been overshadowed by other physically and emotionally trying aspects of the initiation period (e.g., Goodale 1995). In many teeth blackening protocols a potential to negatively impact the subjects' health status can certainly be identified.

The initial application of teeth blackener often involved pasting a generous dose of the respective mixture on the teeth. This raises the issue of acute toxicity by ingesting either a large amount of certain plant metabolites, such as phenolics or saponins, and/or minerals. However, this first blackening was often associated with a period of more of less ritualized deprivation during which food intake was prohibited, and only small amounts of liquids were drunk in a way that avoided any contact with the teeth; e.g., described for male initiates among the Kaulong of southwestern New Britain who 'slept with egit (teeth blackener)' for a week (Goodale 1995). While these precautions were stipulated to ensure the success of the blackening operation, they helped to limit the absorption of teeth blackener. Acute toxicity issues also arose from the use of commercially available mineral salts (with potential impurities such as arsenic) that replaced older, more cumbersome approaches as the practice was adapted (Huard 1951, Staal 1923-1924)

A greater danger must be seen in the repeated, if not daily application of certain teeth blackeners. A significant chronic exposure risk originated from the use of wood tars, which were derived from the incomplete combustion of woody plants and were chemically closely related to wood creosote. Such processes generate an undetermined amount of polycyclic aromatic hydrocarbons, a class of chemicals known to be carcinogenic and teratogenic (Bjørseth \& Ramdahl 1985).

Associated, though not to be equated with the actual teeth blackening process was the chewing of betel. The basic betel quid, with slices of the seed of areca palm (Areca catechu L., Arecaceae) and slaked lime (calcium hydroxide) wrapped in a betel leaf (Piper betle L., Piperaceae) (Zumbroich 2008), was widely considered a way to maintain the dark color of teeth (see also Figure 2). In some places, actual areca nut was included in teeth blackening mixtures, elsewhere teeth blackener was added to betel quids, e.g., by Toqabaqita of North Malaita (Solomon Islands; Lichtenberk 2008). There is mounting evidence that nitrosamines derived from areca nut constitute a cancer risk that was also applied to these teeth blackening activities (IARC 2004, Secretan et al. 2009). The carcinogenic risk was potentiated after the European introduction of Nicotiana tabacum L. Not only did tobacco become an integral ingredient of betel quids in the seventeenth cen- 
tury, but the ability of tobacco to darken teeth was specifically utilized by chewing it combined with $E$. pinnatum or dipping wads of tobacco into flavored iron solutions (Zumbroich 2009).

\section{The risk-benefit balance}

Data presented here (Table 1) indicate that teeth blackeners were frequently prepared from those parts of medicinal plants that served multiple therapeutic uses including oral applications. When effective teeth blackeners were sought out amongst locally available ethnobotanical resources, this criterion correlated positively with a high content of phenolics, iridoids, etc. and favored the use of agents that conveyed oral and other benefits. Even though little is known how the actual selection of agents was accomplished, the process of teeth blackening appears to have been one of the determinants of indigenous oral health, particularly when their health status had been compromised by the teeth filing procedure. It is also biologically plausible that teeth blackening addressed some of the most frequent causes of morbidity and mortality where it was practiced, namely gastrointestinal diseases, infections and malaria (Damon 1974). It remains unresolved, whether the regular ingestion of certain soils in the course of teeth blackening conveyed additional dietary or medical benefits, as has been demonstrated in other instances of geophagy (Skinner et al. 2003). The formulation and manner of application of most blackening agents limited the inherent risk of acute toxicity to some degree. However, long-term exposure to those teeth blackeners with an associated cumulative risk of various cancers had the potential to adversely affect life expectancy.

\section{Beyond the study area}

A perspective of dental practices beyond the study area will shed further light on the relationship between teeth blackening and oral care. While betel chewing was highly prevalent across the Indian subcontinent, teeth blackening was practiced there only in very circumscribed contexts. On the other hand, methodologically diverse traditions of dental care can be traced to an early date. The Buddha's (ca. 563 - 483 BCE) legendary use of tooth sticks left a record of dantadhāvana, tooth cleansing with twigs, as part of his daily hygiene. Diverse medical practices were canonized in the first centuries of the common era in the early ayurvedic treatises Carakasaminitā (Sūtrasthāna 5.71-5.80, Sharma 1981-1994) and Suśrutasaṃitā (Cikitsāsthāna 24.4-24.14, Srikantha Murthy 2000-2001), which detailed the prescribed daily routines for oral care. These comprised the cleaning of teeth with tooth sticks (dantadhāvana), fashioned from the twigs of specific plant species, but also gargles and chews. East of the study area, in Polynesia and outside of the betel chewing region, white teeth were consistently preferred over darkened teeth. Less is known about traditional oral care in this region, but there is evidence that diverse plant ma- terials, such as the pedicle of the fruit of Pandanus sp. (Pandanaceae) or masticated sugar cane were used as mechanical tooth cleaners (Elvin-Lewis \& Lewis 1984, Titcomb 1948).

In Southeast Asia and Melanesia, on the other hand, chewing sticks or simple tooth brushes other than the husk of the areca nut (see above) were rarely recorded. One notable exception was the use of dried roots of Sida rhombifolia L. (Malvaceae) in Central Sulawesi to pick the teeth in order to prevent tooth loss (Kruyt 1938). Regular use of abrasive tooth powders like the ash of areca nut, which was popular in the ayurvedic tradition (Nadkarni 1908), was generally avoided in teeth blackening communities, so as not to abrade the previously applied blackened layer. As a case in point, one may cite the use of fine quartz sand for tooth polishing by the Pinatubo Ayta, one of the Negrito populations of Luzon, who, unlike neighboring groups, did not blacken their teeth (Winters 1977).

In certain parts of South America, e.g, amongst Jivaroan speakers of the upper Amazon basin of Ecuador and Peru, teeth blackening used to be a common practice. It was typically accomplished by chewing the leaves or other parts of one or more plants, such as Calatola costaricensis Standl. (Icacinaceae), Manettia divaricata Wernham (Rubiaceae) or Neea parviflora Poepp. \& Endl. (Nyctaginaceae). Based on indigenous testimony and the apparent absence of other forms of dental care, teeth blackening was recognized as the most important means of 'preventive dentistry' amongst the Jivaroan people (Ayala Flores 1984, Lewis \& Elvin-Lewis 1984). Its efficacy has been related to the presence of polyphenols and the content of fluoride in some of the leaves (Elvin-Lewis et al. 1989, Lewis \& Elvin-Lewis 2003). Incidental observations on the status of oral health amongst habitual blackeners versus those that had abandoned the habit, indicated a decline in the latter group (Lewis \& Elvin-Lewis 1984).

\section{Medical practice and symbolic meanings}

So far the narrative has focused on those medical aspect of teeth blackening that can productively be explored from a Western biomedical vantage point. However, attempting to deconstruct the process of teeth blackening by only referring to the chemical qualities of the plants and minerals involved, will fail to unlock the significance of some of the process and its components, as the following examples can illustrate.

The symbolism of colors conveyed meaning not only to the actual transformation of the teeth, but also sometimes to the steps along the process. Young Lau people of Malaita prepared their teeth blackener from ogo, a rock with high iron content, and the leaves of an Acacia sp. (Fabaceae). This mixture was wrapped in the bright red leaf of a 'dracaena' (most likely Cordyline fruticosa (L.) A. Chev., Asparagaceae), to be smoked in the fire before 


\section{Zumbroich - To Strengthen the Teeth and Harden the Gums - Teeth blackening as medical practice in Asia, Micronesia and Melanesia}

application. Depending on the leaves' color, they played a role in different ceremonial and magical procedures in Lau culture, as well as elsewhere in Melanesia. While dili, thin green leaves, had the power to hurt a person, hango, red leaves, could ward off dangers from both creatures of the physical as well as of the spiritual realm (Ivens 1930, Ross et al. 2008). Such a protective role likely resonated when involving these red leaves in the preparation of teeth blackener.

The complexes of beliefs and values that informed notions of health, needless to say, differed locally and often provided explanations for teeth blackening that do not reconcile easily with the paradigm of Western biomedicine. In parts of the Oceanic world, teeth blackening (but never teeth filing), became part of the elaborate ritual cycles celebrating different life stages. Amongst the Mengen of south-central New Britain blackening the teeth by applying pae, manganese earth, combined with the sap of tavalina (Eugenia sp.) was an obligatory act for any unmarried man and had to precede marriage and sexual intercourse. The smell and taste of teeth blackener was likened by Mengen to that of menstrual blood, the latter considered a significant source of pollution for men. Blackener was applied as a 'vaccine' that inured the wearer to the noxious emanations to be experienced during future sexual encounters. (Laade 1999, Panoff 1970).

Among the Marind-anim of southwestern New Guinea teeth blackening was deeply integrated into the physically challenging maturity rituals of the Mayo cult. The teeth blackener was prepared by medicine men who did not reveal its contents to the initiates, except that it contained a 'secret and surprisingly powerful medicine'. It turns out that this key ingredient that was added to a base of black clay (kahār) consisted of mixed sexual secretions collected during previous ritual heterosexual activity. Not only were these supposed to add permanency to the coloring, but were also known to promote growth and health in other contexts (Baal \& Verschueren 1966, Wirz 1922-1925).

In Southeast Asia, the two processes of teeth filing and blackening had multiple connections on both a physical and metaphysical level. If the intention of teeth filing was to remove part of the teeth based on different, culturally inspired motivations, e.g., as sacrifice, to remove the aggressive element and humanize one's appearance, then teeth blackening aided the intended result by making the remainder of the teeth 'disappear' visually. At the same time blackening served a medicinal function, as it was believed to and, indeed, did help to deal with the potentially life threatening aftermath of the filing operation. Yet teeth filing itself could also be ascribed a cosmologically motivated influence on health and fertility. For example, long teeth were thought to hurt the kao, life spirit, of children born to parents with uncut teeth, among West Torajas of Central Sulawesi (Kruyt 1938), and those children would therefore die young.

\section{Conclusions}

Across a wide geographic area of pre-colonial Asia and Oceania teeth blackening came to hold a unique place among the different physical modifications of the human body: A combination of plant products and minerals were applied to the teeth to convey a visual message, but, as I have shown, indigenous practitioners in many communities also associated the process with specific improvements to the health of their teeth and gums. In particular, teeth blackening appears to have evolved in conjunction with the challenging ritual of teeth filing so common in Island Southeast Asia that carried a high risk of oral complications. The argument for teeth blackening as a significant form of preventive oral care in Southeast Asia and parts of Oceania is also lent support by the relative paucity of other, ethnobotanically diverse methods of dental hygiene in the area. Previous studies amongst Jivaroan people of the Peruvian Amazon region, have similarly suggested that teeth blackening was the primary, if not only method of oral health maintenance.

The data presented here indicate that ethnomedically valued plants were frequently selected for the practice. One explanation how indigenous practitioners arrived at bioactively potent agents was the fact that teeth blackening was often mediated by the same classes of phytochemicals that could also convey medicinal benefits. It remains unclear what, if any, other specific strategies were employed to improve the medicinal benefits from the practice over the many centuries this practice existed. For some plant species or genera involved in the practice, specific activities have been ascribed to identified constituents; in other cases, e.g., for E. pinnatum, detailed phytochemical studies are still lacking. Traditionally used teeth blackeners therefore provide a prescreened group of potentially bioactive plant extracts which warrant future pharmacological studies to analyze their efficacy and safety in oral or other applications.

This paper does not seek to conclude that the practice of teeth blackening was exclusively informed by medicinal considerations. On the contrary, teeth blackening must be recognized as a complex phenomenon, of which the medical aspect is but one significant component inextricably interwoven with other cultural constructs. Teeth blackening was deeply integrated into processes of social maturation and endowed with complex symbolic associations, often of a sexual nature. Herein might lie the 'secret' to the remarkably wide-spread adoption of this practice in so many cultures of Asia, Micronesia and parts of Melanesia (and, in fact, beyond): It was the unique dynamic of medical utility embedded in diverse symbolic ascriptions that made blackening teeth so attractive. 


\section{Acknowledgments}

This manuscript benefited from discussions with Memory Elvin-Lewis (Washington University, St. Louis), Peter Reichart (Charité, Virchow Klinikum, Berlin), Brian Stross (University of Texas, Austin) and Barbara von Tobel (Austin). Warren H. J. Kuo (National Taiwan University) and Hsin-Fu Yen (National Museum of Natural Science, Taiwan) provided data from rare Taiwanese sources. Srujana Doddi (University of Texas, Austin) helped with access to literature. Analyn Salvador-Amores (Baguio) and Hans Brandeis (Berlin), generously contributed Figures 1 and 2, respectively, from their collections.

\section{Literature cited}

Adriani, N. \& A.C. Kruyt. 1912. The Bare'e-sprekende Toradja's van Midden-Celebes. 4 volumes. Landsdrukkerij, Batavia.

Afroz, S., M. Alamgir, M.T.H. Khan, S. Jabbar, N. Nahar \& M.S.K. Choudhuri. 2006. Antidiarrhoeal activity of the ethanol extract of Paederia foetida Linn. (Rubiaceae). Journal of Ethnopharmacology 105(1-2):125-130.

Alviano, D.S., K.F. Rodrigues, S. Leitão, M.L. Rodrigues, M. Matheus, P. Fernandes, A. Antoniolli \& C.S. Alviano. 2004. Antinociceptive and free radical scavenging activities of Cocos nucifera L. (Palmae) husk fiber aqueous extract. Journal of Ethnopharmacology 92(2-3):269-273.

Alviano, W.S., D.S. Alviano, C. Diniz, A. Antoniolli, C. Alvianok, L. Farias, M. Carvalho, M. Souza \& A.M. Bolognese. 2008. In vitro antioxidant potential of medicinal plant extracts and their activities against oral bacteria based on Brazilian folk medicine. Archives of Oral Biology 53(6):545-552.

Anonymous. 1894. Beschrijving der Tentoonstelling te Mageland van Producten van Inlandsche Rijverheid uit de Residentie Kedoe gehouden op 20, 21 en 22 Augustus 1891. Landsdrukkerij, Batavia.

Arias, B.Á. \& L. Ramón-Laca. 2005. Pharmacological properties of citrus and their ancient and medieval uses in the Mediterranean region. Journal of Ethnopharmacology $97(1): 89-95$.

Ayala Flores, F. 1984. Notes on some medicinal and poisonous plants of Amazonian Peru. Pp. 1-8 in Ethnobotany in the Neotropics. Edited by G.T. Prance \& J.A. Kallunki. Advances in Economic Botany, Volume 1. New York Botanical Garden, Bronx, New York.

Baal, J.van \& J. Verschueren. 1966. Dema: Description and Analysis of Marind-anim Culture (South New Guinea). Translation series (Koninklijk Instituut voor Taal-, Land- en Volkenkunde) 9. Martinus Nijhoff, The Hague.
Bailit, H.L. 1968. A possible benefit from tooth-blackening. American Anthropologist, n.s. 70(2):348-53.

Bjørseth, A. \& T. Ramdahl. 1985. Editors of Handbook of Polycyclic Aromatic Hydrocarbons. Volume 2: Emission sources and recent progress in analytical chemistry. $\mathrm{M}$. Dekker, New York.

Bonifacy, G.S. \& T. Yi-Tch'ou. 1908. Le barbares soumis du Yunnan. Bulletin de l'Ecole Française d'Extrême-Orient 8(1):149-176.

Boonnak, N., C. Karalai, S. Chantrapromma, C. Ponglimanont, H.-K. Fun, A. Kanjana-Opas \& S. Laphookhieo. 2006. Bioactive prenylated xanthones and anthraquinones from Cratoxylum formosum ssp. pruniflorum. Tetrahedron 62(37):8850-8859.

Boonnak, N., C. Karalai, S. Chantrapromma, C. Ponglimanont, A. Kanjana-Opas, K. Chantrapromma \& H.-K. Fun. 2007. Quinonoids from the barks of Cratoxylum formosum ssp. pruniflorum. Canadian Journal of Chemistry 85(5):341-345.

Boonnak, N., C. Karalai, S. Chantrapromma, C. Ponglimanont, H.-K. Fun, A. Kanjana-Opas, K. Chantrapromma \& S. Kato. 2009. Anti-Pseudomonas aeruginosa xanthones from the resin and green fruits of Cratoxylum cochinchinense. Tetrahedron 65(15):3003-3013.

Born. 1904. West-Karolinen: Gesundheitsverhältnisse. Arbeiten aus dem Kaiserlichen Gesundheitsamte 21(1):115137.

Brown, N.E. 1882. The Tonga plant (Epipremnum mirabile Schott). Journal of Botany 20:332-337.

Bugenhagen, S. \& R. Bugenhagen. 2007. Ro ta ipiyooto sua Mbula Uunu = Mbula-English Dictionary. Summer Institute of Linguistics, Papua New Guinea.

Burg, C.L. van der. 1885. De Geneesheer in Nederlandsch-Indië. Volume 3: Materia Indica. Martinus Nijhoff, 'S Gravenhage, the Netherlands.

Burkill, I.H. 1935. A Dictionary of the Economic Products of the Malay Peninsula. 2 volumes. Crown Agents for the Colonies, London.

Cambie, R.C. \& J. Ash. 1994. Fijian Medicinal Plants. CSIRO, Melbourne.

Chan, L.W., E.L.C. Cheah, C.L.L. Saw, W. Weng \& P.W.S. Heng. 2008. Antimicrobial and antioxidant activities of Cortex Magnoliae officinalis and some other medicinal plants commonly used in South-East Asia. Chinese Medicine 3:15. 


\section{Zumbroich - To Strengthen the Teeth and Harden the Gums - Teeth blackening as medical practice in Asia, Micronesia and Melanesia}

Chen, L.M.J. \& I.M. Turner. 1998. The use of Epipremnum pinnatum (Araceae) in Singapore in the treatment of cancer: An unreported application of a herbal medicine. Economic Botany 52(1):108-109.

Chen, Y.-F., Y. Huang, W.-Z. Tang, L.-P. Qin, H.-C. Zheng. 2009. Antinociceptive activity of Paederosidic Acid Methyl Ester (PAME) from the n-butanol fraction of Paederia scandens in mice. Pharmacology, Biochemistry and Behavior 93(2):97-104.

Chyau, C.-C., P.-T. Ko \& J.-L. Mau. 2006. Antioxidant properties of aqueous extracts from Terminalia catappa leaves. LWT - Food Science and Technology 39(10):10991108.

Clercq, F.S.A. de. 1909. Nieuw Plantkundig Woordenboek voor Nederlandsch Indië. De Bussey, Amsterdam.

Damon, A. 1974. Human ecology in the Solomon Islands: Biomedical observations among four tribal societies. Human Ecology 2(3):191-215.

Dawes, C. 2008. Salivary flow patterns and the health of hard and soft oral tissues. Journal of the American Dental Association 139(2):18S-24S.

Dell'Agli, M., G. Galli, Y. Corbett, D. Taramelli, L. Lucantoni, A. Habluetzel, O. Maschi, D. Caruso, F. Giavarini, S. Romeo, D. Bhattacharya \& E. Bosisio. 2009. Antiplasmodial activity of Punica granatum L. fruit rind. Journal of Ethnopharmacology 125(2):279-285.

Dring, J.V., G.C. Kite, R.J. Nash \& T. Reynolds. 1995. Chemicals in aroids: A survey, including new results for polyhydroxy alkaloids and alkylresorcinols. Botanical Journal of the Linnean Society 117(2):1-12.

Dutt, U.C. \& G. King. 1877. The Materia Medica of the Hindus: Compiled from Sanskrit medical works. Thacker, Spink \& Co., Calcutta.

Elvin-Lewis, M. \& W.H. Lewis. 1984. The use of nature's toothbrush: The chewing stick. National Geographic Society. Research Reports 16:211-231.

Elvin-Lewis, M., W.H. Lewis \& E. Moeller. 1989. Antiplaque effects of Amazonian tooth blackening plants. Journal of Dental Research 68:408.

Esquenazi, D., M. Wigg, M. Miranda, H. Rodrigues, J. Tostes, S. Rozental, A. da Silva \& C.S. Alviano. 2002. Antimicrobial and antiviral activities of polyphenolics from Cocos nucifera Linn. (Palmae) husk fiber extract. Research in Microbiology 153(10):647-652.

Fan, Y. M., L.Z. Xu, J. Gao, Y. Wang, X.H. Tang, X.N. Zhao \& Z.X. Zhang. 2004. Phytochemical and antiinflammatory studies on Terminalia catappa. Filoterapia 75(3-4):253260.

Filet, G.J. 1855. De Planten in den Botanischen Tuin bij het Groot Militair Hospitaal te Weltevreden. Lange \& Co., Batavia.

Fitzpatrick, S.G. \& J. Katz. 2009. The association between periodontal disease and cancer: A review of the literature. Journal of Dentistry 38(2):83-95.

Flacourt, É.de. 2007. Histoire de la Grande Isle Madagascar. Édition annotée, augmentée et présentée par Claude Allibert. Karthala, Paris.

Flynn, M. 1977. Black teeth: A primitive method of caries prevention in Southeast Asia. Journal of the American Dental Association 95(1):96-97.

Ford, J.F. 1974. The Local Histories of Yünnan. China Society Occasional Papers 19. China Society, London.

Gamble, J.S. 1878. List of the Trees, Shrubs and Large Climbers, Found in the Dajeeling District, Bengal. Bengal Secretariat Press, Calcutta.

Garvan, J.M. 1931. The Manóbos of Mindanao. National Academy of Science, Washington, DC.

Garvan, J.M. 1964. The Negritos of the Philippines. Edited by Hermann Hochegger, Wiener Beiträgezur Kulturgeschichte und Linguistik 14. Ferdinand Berger, Wien.

Gleichauf, R.E. 1979. Intentional deformation in aboriginal northern Borneo: Archaeological evidence. Archaeology and Physical Anthropology in Oceania 14(2):129-135.

Goodale, J.C. 1995. To Sing with Pigs is Human: The concept of person in Papua New Guinea. University of Washington Press, Seattle, London.

Gould, S.W., M.D. Fielder, A.F. Kelly \& D.P. Naughton. 2009. Anti-microbial activities of pomegranate rind extracts: Enhancement by cupric sulphate against clinical isolates of S. aureus, MRSA and PVL positive CA-MSSA. Complementary and Alternative Medicine 9:23.

Grosvenor, P. W., P.K. Gothard, N.C. McWilliam, A. Supriono \& D.O. Gray. 1995. Medicinal plants from Riau Province, Sumatra, Indonesia. Part I: Uses. Journal of Ethnopharmacology 45(1):75-95.

Gutiérrez, R.M.P., S. Mitchell \& R.V. Solis. 2008. Psidium guajava: A review of its traditional uses, phytochemistry and pharmacology. Journal of Ethnopharmacology 117(1):1-27. 
Hagen, B. 1884. Die künstlichen Verunstaltungen des Körpers bei den Batta. Zeitschrift für Ethnologie 16:217225.

Harris, N.O., F. García-Godoy \& C. N. Nathe. 2009. Primary Preventive Dentistry. $7^{\text {th }}$ ed. Pearson, Upper Saddle River, New Jersey.

Hasskarl, J.K. 1845. Aanteekeningen over het Nut, door de Bewoners van Java aan eenige Planten van dat Eiland Toegescheven. Johannes Müller, Amsterdam.

Headland, T.N. 1977. Teeth mutilation among the Casiguran Dumagat. Philippine Quarterly of Culture and Society 5:54-64.

Heyne, K. 1950. De Nuttige Planten van Indonesië. 2 volumes. W. van Hoeve, S' Gravenhage, the Netherlands.

Hoskins, J. 1990. Doubling Descent, Deities and personhood: An exploration of Kodi gender categories. Pp. 273306 in Power and Difference: Gender in island Southeast Asia. Edited by J. Atkinson \& S. Errington. Stanford University Press, Palo Alto, California.

Huard, P. 1951. Teeth-blackening in Eastern Asia and Indo-China. Asia: Asian Quarterly of Culture and Synthesis 1(2,4):197-205, 532-538.

IARC. 2004. Betel-quid and areca-nut chewing and some areca-nut-derived nitrosamines. IARC Monographes on the Evaluation of Carcinogenic Risks to Humans 85:1334.

Institute of Materia Medica. 1990. Medicinal Plants in Viet Nam. World Health Organization, Manila; Institute of Materia Medica, Hanoi.

Ivens, W.G. 1918. Dictionary and Grammar of the Language of Sa'a and Ulawa, Solomon Islands. Carnegie Institution, Washington .

Ivens, W.G. 1930. The Island Builders of the Pacific. Seeley, Service \& Co., London

Jonville, C., H. Kodja, L. Humeau, J. Fournel, P. De Mol., M. Cao, L. Angenot \& M. Frédérich. 2008. Screening of medicinal plants from Reunion Island for antimalarial and cytotoxic activity. Journal of Ethnopharmacology 120(3):382-386.

Kennedy, Raymond. 1953. Field Notes on Indonesia: South Celebes 1949-1950. Edited by H.C. Conklin. Human Relations Area File, New Haven, Connecticut.

Khare, C.P. 2004. Indian Herbal Remedies: Rational Western therapy, Ayuvedic and other traditional usage, botany. Springer Verlag, Berlin.
Kinoshita, S., Y. Inoue, S. Nakama, T. Ichiba \& Y. Aniya. 2007. Antioxidant and hepatoprotective actions of medicinal herb, Terminalia catappa L. from Okinawa Island and its tannin corilagin. Phytomedicine 14(11):755-762.

Kruyt, A.C. 1938. De West-Toradjas of Midden-Celebes. 5 volumes. N. V. Noord-Hollandsche Uitgevers-Maatschappij, Amsterdam.

Laade, W. 1999. Music and Culture in South-East New Britain. Peter Lang, Bern.

Lansky, E.P. \& R.A. Newman. 2007. Punica granatum (pomegranate) and its potential for prevention and treatment of inflammation and cancer. Journal of Ethnopharmacology 109(2):177-206.

Leendertz, C.J. 1890. Van Atjeh's Stranden tot de Koraalrotsen van Nieuw-Guinea: Schetsen uit Insulinde. K. van der Zande, Arnhem.

Lewis, W.H. \& M. Elvin-Lewis. 1984. Plants and dental care among the Jivaro of the Upper Amazon Basin. Pp. 53-61 in Ethnobotany in the Neotropics. Edited by G.T. Prance \& J.A. Kallunki. Advances in Economic Botany, Volume 1. New York Botanical Garden, Bronx, New York.

Lewis, W.H. \& M. Elvin-Lewis. 2003. Medical Botany: Plants affecting human health. 2nd edition. John Wiley \& Sons, Hoboken, New Jersey.

Lichtenberk, F. 2008. A Dictionary of Toqabaqita (Solomon Islands). Pacific Linguistics 592. Pacific Linguistics, Research School of Pacific and Asian Studies, Australian National University, Canberra.

Ling, S.-K., T. Tanaka \& I. Kouno. 2001. Iridoids from Rothmannia macrophylla. Journal of Natural Products 64(6):796-798.

Liu, J. 1995. Pharmacology of oleanolic acid and ursolic acid. Journal of Ethnopharmacology 49(2):57-68.

McCarrell, E.M., S.W. Gould, M.D. Fielder, A.F. Kelly, W. El Sankary \& D.P. Naughton. 2008. Antimicrobial activities of pomegranate rind extracts: Enhancement by addition of metal salts and vitamin C. Complementary and Alternative Medicine 8:64.

Morga, A. de. 1904. Sucesos de las Islas Filipinas. Pp. 25-210 in The Philippine Islands 1493-1898. Volume 16: 1609. Edited by E.H. Blair \& J.A. Robertson. Arthur H. Clark, Cleveland, Ohio.

Muganga, R., L. Angenot, M. Tits \& M. Frédérich. 2010. Antiplasmodial and cytotoxic activities of Rwandan medicinal plants used in the treatment of malaria. Journal of Ethnopharmacology 128(1):52-57. 


\section{Zumbroich - To Strengthen the Teeth and Harden the Gums - Teeth blackening as medical practice in Asia, Micronesia and Melanesia}

Nadkarni, K.M. 1908. Indian Plants and Drugs: With their medical Properties and Uses. Norton \& Co, Madras, India.

Newell, L.E. \& F.B. Poligon. 2005. Batad-Ifugao Dictionary with Ethnographic Notes. Linguistic Society of the Philippines, Manila.

Nguyen, L.H.D. \& L.J. Harrison. 1998. Triterpenoid and xanthone constitutents of Cratoxylum cochinchinense. Phytochemistry 50(3):471-476.

Nicoletti, M., W.A. Chapya, I. Messana, C. Galeffi, M. Sperandei \& G.B. Marini-Bettolo. 1984. New iridoid glucosides from two Rubiaceae: Mussaenda arcuata Lam. and Tarenna graveolens (S. Moore) Bremek. Gazzetta Chimica Italiana 114(1-2):49-53.

Osman, H., A.A. Rahim, N.M. Isa \& N.M. Bakhir. 2009. Antioxidant activity and phenolic content of Paederia foetida and Syzygium aqueum. Molecules 14(3):970-978.

Palanuvej, C. \& N. Ruangrungsi. 2008. Volatile constituents of Cratoxylum formosum ssp. pruniflorum. Journal of Health Research 22(1):53.

Panoff, F. 1970. Maenge remedies and conception of disease. Ethnology 9(1):68-84.

Parkinson, R. 1907. Dreißig Jahre in der Südsee: Land und Leute, Sitten und Gebräuche im Bismarckarchipel und auf den deutschen Salomoinseln. Strecker \& Schröder, Stuttgart.

Parry, N.E. 1932. The Lakhers. Macmillan, London.

Pedraza-Chaverri, J., N. Cárdenas-Ródriguez, M. Orozco-lbarra \& J.M. Pérez-Rojas. 2008. Medicinal properties of mangosteen (Garcinia mangostana). Food and Chemical Toxicology 46(10):3227-39.

Perry, L.M. 1980. Medicinal plants of East and Southeast Asia: Attributed properties and uses. Massachusetts Institute of Technology Press, Cambridge, Massachusetts.

Petti, S. \& C. Scully. 2009. Polyphenols, oral health and disease: A review. Journal of Dentistry 37(6):413-423.

Pihlstrom, B., B.S. Michalowicz \& N.W. Johnson. 2005. Periodontal diseases. Lancet 366(9499):1809-1820.

Pinto, M.M.M., M.E. Sousa \& M.S.J. Nascimento. 2005. Xanthone derivatives: New insights in biological activities. Current Medicinal Chemistry 12(21):2517-2538.

Pradhan, B.K. \& H.K. Badola. 2008. Ethnomedicinal plant use by Lepcha tribe of Dzongu valley, bodering Khangchendzonga Biosphere Reserve, in North Sik- kim, India. Journal of Ethnobiology and Ethnomedicine 4(22):1-18.

Quang, D.N., T. Hashimoto, M. Tanaka, N.X. Dung \& Y. Asakawa. 2002. Iridoid glucosides from roots of Vietnamese Paederia scandens. Phytochemistry 60(5):505-514.

Quisumbing, E. 1951. Medicinal Plants of the Philippines. Department of Agriculture and Natural Resources, Technical Bulletin 16. Bureau of Printing, Manila.

Reid, A. 1988. Southeast Asia in the Age of Commerce, 1450-1680. Volume 1. Yale University Press, New Haven, Connecticut.

Reis Altschul, S. von. 1973. Drugs and Foods from Little-known Plants. Harvard University Press, Cambridge, Massachusetts.

Rinaldi, S., D.O. Silva, F. Bello, C.S. Alviano, D.S. Alviano, M. Matheus \& P. Fernandes. 2009. Characterization of the antinociceptive and anti-inflammatory activities from Cocos nucifera L. (Palmae). Journal of Ethnopharmacology 122(3):541-546.

Ringer, S. \& W. Murrell. 1880. On Tonga: A remedy for neuralgia, used by the natives of the Fiji Islands. Lancet (March 6th, 1880):360.

Rongmuthu, D.S. 1960. The Folktales of the Garo. University of Gauhati, Dept. of Publications, Gauhati, India.

Ross, M., A. Pawley \& M. Osmond. 2008. Editors of The Lexicon of Proto Oceanic: The culture and environment of ancestral Oceanic society. Volume 3: Plants. Pacific Linguistics, Research School of Pacific and Asian Studies, Australian National University, Canberra.

Rumphius, G.E. 1747. Het Amboinsche Kruid-boek, Herbarium Amboinense. Volume 5. Fransicum Changuion, Hermannum Uytwerf, Amsterdam.

Rumphius, G.E. 1999. The Ambonese Curiosity Cabinet. Translated, edited and annotated by E.M. Beekman. Yale Unversity Press, New Haven, Connecticut.

Sallet, A. 1928. Les laquages des dents et les teintures dentaires chez les Annamites. Bulletin des Amis du Vieux Hué 15(4):223-254.

Schellong, O. 1890. Die Jắbĭm-Sprache der Finschhafener Gegend (N.O. Neu-Guinea; Kaiser Wilhelmsland). Wilhelm Friedrich, Leipzig.

Schildkrout, E. 2004. Inscribing the body. Annual Review of Anthropology 33:319-344. 
Secretan, B., K. Straif, R. Baan, Y. Grosse, F. El Ghissassi, V. Bouvard, L. Benbrahim-Tallaa, N. Guha, C. Freeman, L. Galichet, V. Cogliano \& on behalf of the WHO International Agency for Research on Cancer Monograph Working Group. 2009. A review of human carcinogens part E: Tobacco, areca nut, alcohol, coal smoke, and salted fish. Lancet Oncology 10(11):1033-1034.

Senfft, A. 1903. Ethnologische Beiträge über die Karolinen-Insel Yap. Petermanns Geographische Mitteilungen 46:49-60.

Sharma, H.K., L. Chhangte \& A.K. Dolui. 2001. Traditional medicinal plants in Mizoram, India. Filoterapia 72(2):146161.

Sharma, P.V. 1981-1994. Editor \& translator of Carakasamphitā: Agnivesha's Treatise refined and annotated by Caraka and redacted by Drọhabala (text with English translation and critical notes). 4 volumes. Jaikrishnadas Ayurveda Series No. 36. Chaukhamba Orientalia, Varanasi, India.

Skinner, H.C.W. \& A.R. Berger. 2003. Editors of Geology and Health: Closing the gap. Oxford University Press, Oxford.

Smith, G. H. 1951. The tooth-sawing operation among the Raday of French Indo-China. Man 51:33.

Srikantha Murthy, K.R. 2000-2001. Editor \& translator of Illustrated Suśruta Saṃhitā: Text, English translation, notes, appendices and index. 4 Volumes. Jaikrishnadas Ayurveda Series No. 102. Chaukhambha Orientalia, Varanasi, India.

Srithi, K., H. Balslev, P. Wangpakapattanawong, P. Srisanga \& C. Trisonthi. 2009. Medicinal plant knowledge and its erosion among the Mien (Yao) in northern Thailand. Journal of Ethnopharmacology 123(2):335-342.

Staal, J. 1923-1924. The Dusuns of North Borneo: Their social life. Anthropos 18-19:958-977.

Steinmetz, E.F. 1961. Tonga. Quarterly Journal of Crude Drug Research 1(3):104-108.

Stewart, G.S., S.A. Jassim, S.P. Denyer, P. Newby, K. Linley \& V.K. Dhir. 1998. The specific and sensitive detection of bacterial pathogens within $4 \mathrm{~h}$ using bacteriophage amplification. Journal of Applied Microbiology 84(5):777-783.

Suddhasthira, T., S.Thaweboon, N. Dendoung, B. Thaweboon \& S. Dechkunakorn. 2006. Antimicrobial activity of Cratoxylum formosum on Streptococcus mutans. Southeast Asian Journal of Tropical Medicine and Public Health 37(6):1156-1159.
Svelmoe, G. \& T. Svelmoe. 1990. Mansaka Dictionary. Summer Institute of Linguistics, Dallas, Texas.

Tan, M.L., T.S.T. Muhammad, N. Najimudin \& S.F. Sulaiman. 2005. Growth arrest and non-apoptotic programmed cell death associated with the up-regulation of c-myc mRNA expression in T-47D breast tumor cells following exposure to Epipremnum pinnatum (L.) Engl. hexane extract. Journal of Ethnopharmacology 96(3):375-383.

Tanaka, T., G.I.Nonaka \& I. Nishioka. 1986. Tannins and related compounds. XLII. Isolation and characterization of four new hydrolysable tannins, terflavins $A$ and $B$, ergallagin and tercatain from leaves of Terminalia catappa $\mathrm{L}$. Chemical and Pharmaceutical Bulletin 34(3):1039-1049.

Tayanin, G.L. \& D. Bratthall. 2006. Black teeth: Beauty or caries prevention? Practice and beliefs of the Kammu people. Community Dentistry and Oral Epidemiology 34(2):81-86.

Titcomb, M. 1948. Kava in Hawaii. Journal of the Polynesian Society 57(2):105-171.

Tronstad, L. 2009. Cinical Endodontics: A textbook. 3rd. Edition. Thieme, New York.

Voravuthikunchai, S.P., T. Sririrak, S. Limsuwan, T. Supawita, T. lida \& T. Honda. 2005. Inhibitory effects of active compounds from Punica granatum pericarp on verocyctotoxin production by enterohermorrhagic Escherichia coli O157 : H7. Journal of Health Science 51(5):590-596.

Vallier. 1898. Étude sur les ressources de la fôret d'Analamazaotra. Colonie d'Madagascar: Notes, Reconnaissance et Exploration 2(9):1184-1208.

Wang, Y.-C. \& T.-L.Huang. 2005. Screening of anti-Helicobacter pylori herbs deriving from Taiwanese folk medicinal plants. FEMS Immunology and Medical Microbiology 43(2):295-300.

Waterhouse, J. H. Lawry. 1949. A Roviana and English dictionary, with English-Roviana index and list of natural history objects and appendix of old customs. Epworth Printing and Publishing House, Sydney.

Wilken, G.A. 1888. lets over de mutilatie der tanden bij de volken van den Indischen Archipel. Bijdragen tot de Taal-, Land- en Volkenkunde van Nederlandsch-Indië 3(3):472504.

Williamson, E.M. 2002. Editor of Major Herbs of Ayurveda. Churchill Livingstone, Edinburgh.

Wilson, C.O. \& T.E. Jones. 1967. American Drug Index. J. B. Lippincott, Philadelphia. 


\section{Zumbroich - To Strengthen the Teeth and Harden the Gums - Teeth blackening as medical practice in Asia, Micronesia and Melanesia}

Winters, N.J. 1977. The meaning of a smile: A crown-toroot analysis of teeth as keys to past population. Pp. 449454 in Filipino Heritage: The metal age in the Philippines. Volume 2. Edited by A.R. Roces. Lahing Pilipino Publishing, Manila.

Wirz, P. 1922-1925. Die Marind-anim von HolländischSüd-Neu-Guinea. 4 parts in 2 volumes. Abhandlungen aus dem Gebiet der Auslandskunde, Band 10 und 16. Abhandlungen aus dem Gebiet der Auslandskunde, Reihe B, Völkerkunde, Kulturgeschichte und Sprachen, Band 6 und 9. L. Friederichsen, Hamburg, Germany.

Yamada, K. 1921. Plants used for chewing and teeth-dyeing by the Paiwans [in Taiwanese]. Journal of the Natural History Society of Taiwan 11(56):173-176.

Yazdi, M.A. \& M. Kamalinejad. 2008. Antibacterial activity of Terminalia catappa against bacteria isolated from burn wounds and comparison with effects of selective antibiotics in vitro. International Journal of Infectious Diseases 12(S1):e410.
Zheng, X. 2002. The culture of the Huayao Dai and its prospects - comparative research on the cultural characteristics of the Dai peoples living in the upper reaches of the Red River. Manusya: Journal of Humanities 5(2):6-15.

Zumbroich, T.J. 2008. The origin and diffusion of betel chewing: A synthesis of evidence from South Asia, Southeast Asia and beyond. EJournal of Indian Medicine 1(3):63-116.

Zumbroich, T.J. 2009. 'Teeth as black as a bumble bee's wings': The ethnobotany of teeth blackening in Southeast Asia. Ethnobotany Research and Applications 7:381-398.

Zumbroich, T.J. \& A. Salvador-Amores. 2009. When black teeth were beautiful' - the history and ethnography of dental modifications in Luzon, Philippines. Studia Asiatica 10:125-165. 
